\title{
Julij Betetto in njegova vloga v upravnem in pedagoškem ustroju ljubljanskega konservatorija
}

\author{
Tina Bohak Adam \\ Univerza v Ljubljani \\ University of Ljubljana
}

Zgodovina ustroja ljubljanskega konservatorija sega v leto 1919, ko je bila realizirana dolgoletna želja odbornikov, da Glasbena matica postane "pravi konservatorij vseh Jugoslovanov «. ${ }^{1}$ Ministrstvo za uk in bogoča$\operatorname{stje}^{2} \mathrm{v}$ Ljubljani je na podlagi dokumentacije konzistorija, izvršnega odbora in članov komisij z odlokom 5. januarja 1920 ustanovilo prvi Jugoslovanski konservatorij za glasbeno in igralsko umetnost, ki je s tem dnem dobil pravico javnosti. ${ }^{3} \mathrm{Na}$ slovenskem ozemlju je bila tako ustanovljena prva ustanova $\mathrm{v}$ zgodovini glasbenega šolstva, katere primarni namen je bilo glasbeno izobraževanje poklicnih glasbenikov v celotni vertikali.

Primarne naloge konservatorija so bile izobraziti kadre, usposobljene za izvajanje orkestralne glasbe, sodelovanje pri opernih predstavah, v simfoničnih in vojaških orkestrih ter izobraževanje opernih pevcev in opernih zboristov ter dramskih igralcev. Ravnatelj Hubad je navajal še potrebe po umetnikih pianistih, violinistih, violončelistih, solistih vseh instrumentov, potrebe po izobrazbi za glasbene učitelje (za poučevanje glasbenega predmeta na glasbenih šolah, gimnazijah, učiteljiščih idr., potrebe po društvih,

$1 \quad$ Izvestje Glasbene matice v Ljubljani o 36. društvenem letu 1907/1908 (Ljubljana: Glasbena matica, 1908), 11.

2 Danes Ministrstvo za izobraževanje, znanost in šport.

3 Narodna in univerzitetna knjižnica (dalje NUK) Ljubljana, Glasbena zbirka, fond Glasbena matica, zapisniki sej odbora Glasbene matice, 28. 1. 1920. 
kapelnikih in korepetitorjih $\mathrm{v}$ gledališčih, koncertnih dirigentih itd.). ${ }^{4} \mathrm{Iz}$ strukture oddelkov in predmetnikov konservatorija je mogoče razbrati, da sta bila kar dva od petih oddelkov neposredno namenjena petju, bodisi je šlo za solistično izobraževanje, bodisi za izobraževanje v operni šoli, kjer so posameznike s študijem posameznih vlog, petjem $\mathrm{v}$ tercetih, kvartetih ipd. ter dodanim odrskih gibom ustrezno pripravili na udejstvovanje v opernih hišah že med študijem oz. po njem. Izjemen poudarek delovanja ustanove na področju solističnega petja ne preseneča, saj je imel pri snovanju posameznih oddelkov zagotovo velik vpliv ravnatelj Matej Hubad, ki je kot pevski pedagog takrat deloval že šestindvajset let.

V prvem letu delovanja se je na konservatorij vpisalo čez 1000 gojencev, kar je posledično pomenilo izjemno pomanjkanje učnih prostorov. Lokacije učilnic so bile tako razporejene po več lokacijah v samem centru Ljubljane, in sicer v hiši Glasbene matice na Vegovi ulici št. 5 in Gosposki ulici št. 8 ter v poslopju Filharmonične družbe na Kongresnem trgu. Njegovo delovanje sta finančno podprla Deželna vlada in deželni odbor. ${ }^{6} \mathrm{Od}$ šolskega leta 1922/23 je imel tri stopnje: nižja stopnja konservatorija je obsegala štiri pripravljalne razrede, srednja stopnja tri letnike in višja prav tako tri letnike - enovit študij je tako obsegal deset let. V kolikor posameznik v določenem razredu oz. letniku ni predelal predpisane snovi, se je študij na konservatoriju lahko podaljšal na enajst, tudi dvanajst let, čeprav je formalno trajal deset let. ${ }^{7}$ Izpostavimo, da je bila kakovost izobraževanja na evropsko primerljivem nivoju, saj so diplomanti konservatorija pogosto odhajali v Prago ali na Dunaj in se brez težav vključevali v študij na visoki stopnji.

Zaradi finančnih težav konservatorija je postajalo vse bolj nujno, da se ustanovo podržavi. Trdnejša pot do tega cilja se je pričela z objavo uredbe o Državnem konservatoriju v Beogradu leta 1921, vendar se kljub prizadevanju ravnatelja Mateja Hubada, predsednika Glasbene matice dr. Vladimirja Ravniharja in Deželne vlade Slovenije zaradi krčenja državnega proračuna to ni zgodilo vse do 5 . januarja 1926, ko je t. i. Jugoslovanski konservatorij

4 Tina Bohak, Julij Betetto (1885-1963) - nestor opernih in koncertnih pevcev (Ljubljana: Akademija za glasbo, 2015), 53 .

5 Matej Hubad, »Jugoslovanski konservatorij Glasbene Matice v Ljubljani«, Učiteljski tovariš 59, št. 34 (1919): 1.

6 Poročilo društva Glasbene matice v Ljubljani o šolskem letu 1933/1934 (Ljubljana: Glasbena matica, 1934), 6; Anon., »Mateju Hubadu«, Slovenski narod 52, št. 145 (1919): 4. Uredništvo, »Nove muzikalije, Nova muzika 2 (1929): 1. 
postal državna ustanova in bil 1. aprila istega leta pripojen državni upravi. ${ }^{8}$ Državni konservatorij in šola Glasbene matice sta se uradno »ločila« v šolskem letu 1926/27. Glasbena šola je naprej delovala samostojno kot osnovna stopnja glasbene vzgoje in izobraževanja, kot pripravljalna šola na višjo stopnjo ali kot ustanova, ki je izobraževala zgolj ljubitelje glasbe. Profesorji so tako postali državni uslužbenci in dobili možnost prejemanja državne pokojnine, kar je mnogim omogočalo boljšo eksistenco. ${ }^{9}$ Državni konservatorij je bil ustanova, ki je temeljila na dobrih metodah poučevanja in profesorjih z veliko znanja in praktičnih izkušenj, kar je nedvomno pripomoglo k vrnitvi bivših študentov po raznih izpopolnjevanjih v Pragi, Rimu in drugod nazaj v Ljubljano, kjer so se uveljavili kot dobri profesorji in poustvarjalci, npr. Marijan Lipovšek, Pavel Šivic, Leon Pfeifer in drugi.

Eden ključnih posameznikov, ki so sodelovali pri snovanju prvega statuta konservatorija je bil, ob tenoristu in režiserju Franju Bučarju ter igralcu in režiserju Ignaciju Borštniku, tudi basist Julij Betetto, ki je v tem času deloval kot eminenten solist v Dunajski državni operi. ${ }^{\circ}$ Poudarimo, da je bil Betetto neločljivo povezan z društvom Glasbena matica tako rekoč od začetka svoje umetniške poti, saj je prve solopevske nauke pridobil pri izvrstnem pevskem pedagogu in dolgoletnem ravnatelju Franu Gerbiču, kasneje pa se je izobraževal pri njegovem nasledniku, Mateju Hubadu, ki je poleg poučevanja, po Gerbičevi smrti, prav tako prevzel vodstveno funkcijo ustanove.

Kot pedagoški uslužbenec se je Betetto profesorskemu zboru konservatorija pridružil sredi 20. let 20. stoletja, ko je konec decembra 1924 prejel s strani odbora Glasbene matice povabilo, da bi kot honorarni sodelavec prevzel nekaj ur solopevskega pouka. Vabilo je sprejel, saj je prve izkušnje na področju solopevskega poučevanja pridobil že v času delovanju v cesarski prestolnici, kjer je poučeval na neki zasebni glasbeni šoli. ${ }^{11}$ Poudarimo, da se je Betetto, zaradi izjemnega domovinskega čuta in osebnih nazorov, kljub mednarodno uveljavljeni in vzpenjajoči se umetniški karieri na Dunaju, želel vrniti v domače okolje in se leta 1922 pridružil narodnostno

8 NUK Ljubljana, Glasbena zbirka, fond Glasbena matica, zapisniki sej odbora Glasbene matice 6. 9. 1921 in 18.11. 1921.

9 Bohak, Julij Betetto (1885-1963) - nestor opernih in koncertnih pevcev, 54-55.

10 NUK Ljubljana, Glasbena zbirka, fond Glasbena matica, zapisniki sej odbora Glasbene matice 24. 3. 1919, 21. 5. 1919 in 14. 7. 1919.

11 Tina Bohak Adam, »Artistic career of Bass Julij Betetto in Ljubljana Opera«, De musica disserenda 14, št. 2 (2018): 76, https://doi.org/10.3986/dmd14.2.05; Bohak, Julij Betetto (1885-1963) - nestor opernih in koncertnih pevcev, 54-55. 
barvitemu opernemu ansamblu ljubljanske Opere. Med odborniki Glasbene matice se je novica kaj hitro razširila in tako ne čudi, da so želeli imeti znotraj kolektiva tako imenitnega umetnika. Betetto je februarja 1925 pričel s poučevanjem gojencev konservatorija na vseh stopnjah - v pripravljalnih razredih, na nižji, srednji in višji stopnji, ${ }^{12}$ kar lahko interpretiramo tako kot potrditev kakovostnega dela kot tudi potrditev pravilnega izbora vsestranskega in spoštovanega posameznika $\mathrm{z}$ mednarodno kariero s strani odbornikov Glasbene matice. Smelo trdilo, da se je tako pričela pisati, ob umetniški tudi Betettova zavidanja vredna pedagoška kariera, ki je dobivala skozi leta vse večje razsežnosti.

Naglasimo, da sta tako široko pedagoško delo opravljala le še Janko Ravnik in Matej Hubad, ki sta imela dovolj visoko izobrazbo za poučevanje. Na konservatoriju so namreč morali imeti popolno, to je visoko izobrazbo, sicer so jih na delo sprejeli le začasno - honorarno. Solopevska pedagoginja Wanda Wistinghausen je bila na primer usposobljena za pouk $\mathrm{v}$ treh letnikih nižje stopnje, Jeanette Foedransperg za pripravljalni razred ter prvi in drugi letnik konservatorija. ${ }^{13}$ Betettu, ki je bil angažiran še v ljubljanski Operi, pedagoško delo ni dovoljevalo velikega števila učencev, zato je konservatorijskemu odboru predlagal, da za pouk nastavi še Franca Pogačnika-Navala, enega imenitnejših svetovnih opernih tenorjev svojega časa, ki je leta 1888 končal študij na dunajskem konservatoriju. ${ }^{14}$ Odbor je Betettov predlog sicer sprejel, a Naval kot solopevski pedagog na ljubljanskem konservatoriju dejansko ni nikoli poučeval. ${ }^{\text {Is }}$

Ob zapisanem se zastavlja vprašanje, zakaj so odborniki povabili k sodelovanju ravno posameznika kot je bil Julij Betetto, saj so se najbrž zavedali dejstva, da bo kot spoštovan basist gotovo v polnosti angažiran na odru ljubljanske Talije in najbrž tudi na gostovanjih zunaj slovenskih meja. Odgovor je treba iskati v širšem zgodovinskem kontekstu Glasbene matice, saj je po smrti izjemnega ravnatelja in pevskega pedagoga Frana Gerbiča leta 1917 zazevala velika praznina. Ravnateljsko mesto in njegove učence je sicer prevzel široko izobraženi Matej Hubad, a sam dela ob ustanovitvi konservatorija zaradi preobširnosti več ni mogel opravljati sam. Potreboval je kvalitetnega in ustrezno usposobljenega pevskega pedagoga, ki bi poučeval

12 Bohak, Julij Betetto (1885-1963) - nestor opernih in koncertnih pevcev, 54-55.

13 NUK Ljubljana, Glasbena zbirka, fond Julij Betetto, mapa Konservatorij, Personalne zadeve.

14 Primož Kuret, Sto slovenskih opernih zvezd (Ljubljana: Prešernova družba, 2005),3435 .

Bohak, Julij Betetto (1885-1963) - nestor opernih in koncertnih pevcev, 55. 
solistično petje, hkrati pa bi tudi pregledal učne načrte za pouk solopetja, ki so nujno potrebovali osvežitev oz. metodološko prenovo. Ob tem naj omenimo, da iz virov sicer ni mogoče ugotoviti, kateri učni načrt za pouk solističnega petja so ob ustanovitvi konservatorija uporabljali, predvidevamo pa, da so bili v uporabi tisti, ki sta jih dopolnila Gerbič in Hubad v šolskem letu 1906/1907 in so temeljili na Gerbičevem učnem načrtu iz leta $1887 .{ }^{16}$ Vsekakor je Betetto s svojo izobrazbo in mednarodno uveljavljeno umetniško kariero ustrezal profilu iskanega pevskega pedagoga.

Ugotavljamo, da je s prihodom Betetta na Državni konservatorij pričelo število gojencev na področju solopevskega izobraževanja v 2o. letih 20. stoletja strmo naraščati. Neizpodbiten dokaz za to je šestinštirideset vpisanih gojencev v šolskem letu 1926/1927, kar je v zgodovini slovenskega glasbenega šolstva zagotovo svojstven fenomen, saj je pouk solopetja presegel celo pouk klavirja in violine, ki sta bila dotlej vsa leta prva na lestvici zanimanja. ${ }^{17} \mathrm{~K}$ temu je najbrž botrovalo tudi dejstvo, da je cenjen in prepoznaven basist dotlej imel za seboj že bleščečo umetniško kariero na Dunaju, kjer je v obdobju 1909-1922 skupno odpel kar tisoč dvesto dvajset nastopov na odrskih in koncertnih deskah. ${ }^{18}$

Julij Betetto je kot honorarni sodelavec na ljubljanskem konservatoriju deloval vse do konca šolskega leta 1929/1930. ${ }^{19}$ Septembra 1930 je namreč odpotoval v Bavarsko državno opero v Münchnu, kjer je dve sezoni pretežno poustvarjal Wagnerjev repertoar, nad katerim sicer ni bil najbolj navdušen. Ne glede na to ali pa prav zaradi tega opažamo širitev njegovega znanja na področju pevske tehnike, ki jo je s pridom prenašal na svoje gojence. ${ }^{20}$

Pred odhodom je bil s strani vodstva Glasbene matice tudi prvič spodbujen $\mathrm{k}$ razmisleku o prevzemu ravnateljskega mesta na konservatoriju, a se zaradi preobilice dela zanj ni odločil, kar je potrdil v enem izmed kasnejših intervjujev. Dejal je:

Ko sem odhajal jeseni 1930 v angažma državne opere $v$ Monakovem, da se naužijem v tradicionalni umetniški atmosferi novih vtisom ter preizkusim svoje zmožnosti $v$ trdi, neizprosni konkurenci in železni disciplini, sem bil prvikrat od merodajne strani opozor-

16 Ibid., 52.

17 Ibid., 54-55.

18 Osebni dnevnik Julija Betetta, brez paginacije.

19 Poročilo društva Glasbene matice v Ljubljani o šolskem letu 1929/193o (Ljubljana: Glasbena matica, 1930), 7 . 
jen, da bi se zanimal za v doglednem času prosto mesto ravnatelja državnega konservatorija. Od tedaj po do mojega povratka zopetno službovanje pri naši operi se zaradi velike zaposlenosti v Monakovem nisem bavil z uresničevanjem te ideje. ${ }^{21}$

Po vrnitvi v Ljubljano, leta 1932, se je kot primarno posvetil pedagoškemu delu, umetniško pa je deloval le še kot stalni gost v ljubljanski Operi. Decembra 1933 je prevzel še mesto ravnatelja Državnega konservatorija. ${ }^{22}$ Kot je znano, je dotedanji ravnatelj matičine glasbene šole in konservatorija Matej Hubad zaradi bolezni od svoje funkcije v šolskem letu 1934/1935 odstopil. Na razpis za vodstveno funkcijo se je v začetku leta 1933 sicer prijavilo pet kandidatov: Julij Betetto, Slavko Osterc, Lucijan Marija Škerjanc, Mirko Pugelj ter Anton Trost, a sta se za mesto ravnatelja resno potegovala le Betetto in Osterc. ${ }^{23}$ Odborniki Glasbene matice so odločili v prid Betettu. Ob tem se postavlja vprašanje, zakaj je bil Julij Betetto primernejši kandidat. Razloge je najbrž treba iskati v dejstvu, da je bil Betetto tradicionalno usmerjen posameznik, ki se ni spogledoval z avantgardo, kar pa ne moremo trditi za Osterca, ki je imel zelo radikalne poglede na slovensko ustvarjalnost in je bil tudi predstavnik avantgardnega skladateljskega kroga. Ljubljansko glasbeno šolstvo je bilo v tem obdobju precej bolj naklonjeno tradiciji in so najbrž posledično pri odločujočih članih Osterčevi avantgardni nazori vzbudili nezaupanje. Prav tako je treba upoštevati, da Osterc, sicer praški študent, ni imel zaključene visoke stopnje konservatorija. ${ }^{24}$ Betetto je zelo preudarno pristopil h kandidaturi, o kateri je v enem izmed intervjujev povedal:

Ko se je pa pred poldrugim letom naš veliki Matej Hubad odločil, da odloži vodstvo zavoda, katerega duša je bil toliko let, je postala zadeva nasledstva resna. Treba se je bilo odločiti! Zavedajoč se dobro, da z morebitno dodelitvijo vodstva najvišjega glasbenega zavoda ni le združeno veliko moralno priznanje, temveč predvsem ogromna odgovornost nasproti državi, narodu in svoji vesti, sem dolgo okleval. Šele na podlagi temeljitih razgovorov, razmišljevanja in sondiranja različnih ' $z a$ ' in 'proti', zaupajoč izkustvom

Emil Adamič, "Naša glasbena univerza, Direktor Betetto govori o svojih delovnih načrtih, «Jutro 15, št. 196 (1934): 3.

Poročilo društva Glasbene matice v Ljubljani o šolskem letu 1933/1934 (Ljubljana: Glasbena matica, 1934): 7 .

23 Bohak, Julij Betetto (1885-1963) - nestor opernih in koncertnih pevcev, 56.

24 Ibid. 
30 letnega umetniškega udejstvovanja, sem se odločil, da prijavim kandidaturo. $^{25}$

Več kot očitno je, da je Hubad želel Betetta za svojega naslednika, saj ga je poznal od začetka glasbenega izobraževanja in je bil med njegovimi najboljšimi učenci, gotovo pa ga je spoštovan in cenil zaradi njegovih uspehov na Dunaju in kasneje tudi v Ljubljani ter v Münchnu, od koder se je preteklo leto vrnil. Tako ni nenavadno, da je ravno Hubad napisal priporočilo $h$ kandidaturi vsestranskega Betetta, v katerem je med drugim zapisal:

[I]zvrsten učitelj, sam velik umetnik, umetniško čuteč in dovršen pevec, s svojimi učenci je dosegel izredne uspehe in jih izvrstno usposobil za njihov bodoči poklic. Bil je vzoren $v$ vseh pogledih in je pozneje z najlepšimi uspehi in velikim ugledom nastopal tudi $v$ tujini. Kot človek je bil plemenitega značaja, strog in skrajno vesten do sebe, ter resnega, a vljudnega ravnanja proti drugim. Povsod je užival velik ugled. Njegova glasbena izobrazba je bila splošna, temeljita ter je odražala pevskega prvaka z izredno finim obnašanjem in sloves pravega resnega umetnika velikih ambicij. ${ }^{26}$

Matej Hubad je kot dolgoletni ravnatelj imel gotovo odločilno besedo pri izbiri in tako je Betetto, kot rečeno, konec leta 1933 postal ravnatelj Državnega konservatorija v Ljubljani in sprejel vse naloge, ki so mu bile zadane kot njegovemu neposrednemu nasledniku. Vselej je z velikim spoštovanjem govoril o svojem učitelju, prijatelju in zavezniku Hubadu ter njegovem izjemnem pomenu za ustanovitev in delovanje konservatorija. Ugotavljamo, da je Betetto s širokim uvidom razmišljal o vseh nalogah, ki mu jih je ta funkcija prinesla v njegovo, že zelo zapolnjeno, umetniško in pedagoško kariero:

$V$ začetku decembra 1933 je padla odločitev. Prevzel sem posle in se $z$ vso intenziteto oprijel nalog, da opravičim veliko zaupanje, ki mi je bilo izkazano z imenovanjem na to odgovorno mesto. Vsekakor težko izvedljiv problem! Biti neposredno naslednik Mateja Hubada, moža, ki predstavlja v glasbeno-kulturnem podvigu Slovencev enkratno, edinstveno pojavo, pomeni delo na temelju prislovnice

25 Adamič, »Naša glasbena univerza, Direktor Betetto govori o svojih delovnih načrtih«, 3-4.

26 NUK Ljubljana, Glasbena zbirka, fond Julij Betetto, mapa Konservatorij, Akademija, poučevanje, Priporočilo Mateja Hubada; Bohak, Julij Betetto (1885-1963) - nestor opernih in koncertnih pevcev, 57. 
'noblesse oblige'. Naslediti moža, katerega glasbeno-vzgojna potenca se vidi in čuti na vseh popriščih glasbenega udejstvovanja našega naroda, pomeni prevzem dolžnosti, katerih izpolnjevanje se bo vedno ocenjevalo in sodilo s stališča omenjenega dejstva. Zavod, katerega vodstvo sem prevzel, je plod neumornega mnogoletnega dela Mateja Hubada. Dela, polnega požrtvovanja in asketičnega samozatajevanja, katerega krona je pač bila ustanovitev prvega jugoslovanskega konservatorija. V kratkih letih od ustanovitve do danes ga je izoblikoval do zavidanja vredne višine. To krono njegovega dela obvarovati škode, izpopolnjevati in lepšati jo $z$ novimi biseri, je problem, katerega razčlenitev mora biti sinteza mojih dolžnosti. ${ }^{27}$

Kmalu po nastopu ravnateljevanja je Betetto pričel z reorganizacijo delovanja konservatorija. Ustanovil je t. i. konservatorijski sosvet, ki je bil kot ene vrste strokovni svet s funkcijo odločanja oziroma soodločanja pri najpomembnejših strokovnih vprašanjih delovanja ustanove. ${ }^{28}$

Kot je dejal, je to

institucija, $v$ katero so zastopani interesi klavirskega, violinskega oziroma instrumentalnega, dalje kompozitorskega oddelka, kako tudi onega za teoretične predmete. V sejah, katerih predseduje ravnatelj, se obravnavajo predvsem vprašanja organizacijskega značaja. Ugotoviti morem, da so se člani sosveta dobro zavedali prevzetih dolžnosti. Izpolnim le prijetno dolžnost, ako jim izrekam na tem mestu svojo zahvalo in priznanje. ${ }^{29}$

Prav tako je leta 1934 reorganiziral pedagoški oddelek, ki je po njegovem mnenju imel prvo in glavno nalogo vzgojiti temeljito in kvalitetno izobražene glasbenike, predvsem bodoče profesorje glasbe. V sodelovanju s člani konservatorijskega sosveta so sestavili nov pravilnik Državnega konservatorija, s katerim je postal pedagoški oddelek najpomembnejši oddelek ustanove, kar je konec maja istega leta Ministrstvo za prosveto tudi potrdilo. ${ }^{30}$ Iz nagovora učiteljskemu zboru ob nastopu službe ravnatelja je razvidno, da si je prizadeval delovati v harmoniji $\mathrm{z}$ učiteljskim zborom, se zave-

Adamič, "Naša glasbena univerza, Direktor Betetto govori o svojih delovnih načrtih«, 3-4.

Bohak, Julij Betetto (1885-1963) - nestor opernih in koncertnih pevcev, 57.

29 Adamič, »Naša glasbena univerza, Direktor Betetto govori o svojih delovnih načrtih«, 3-4.

30 Ibid. 
dal pomembnosti svoje funkcije in dolžnosti, poudaril pa je še, da goji do zavoda veliko ljubezen. ${ }^{31} \mathrm{O}$ pomenu dobrega glasbenega pedagoga, ne le pri glasbeni, ampak tudi splošni vzgoji otrok in mladostnikov, je po prvem letu uspešnega ravnateljevanja med drugim povedal:

Mirnega srca lahko trdim, da bodo absolventi, ki bodo izpolnili vse zahteve novega obsežnejšega pravilnika, v polni meri dorasli svojemu vzvišenemu poslanstvu - glasbeni vzgoji zaupane jim mladine. Gojenec, ki želi svojo glasbeno nadarjenost izoblikovati na državnem konservatoriju, ne prevzame pri vstopu samo pravic, temveč tudi dolžnosti. Te niso plod duhomorne, šomaštrije', temveč sistematičnega vzgojeslovja. Gojenec, ki zapusti kot absolvent državni konservatorij, naj ne bo le dober glasbenik, on mora biti tudi vreden član človeške družbe, veren sin države in svojega naroda, ki je vedno in povsod sposoben nastopati kakor človek olike in takta. ${ }^{32}$

Kot ravnatelj je stremel tudi k prenovi in dopolnitvi učnih načrtov, ne le glavnih, ampak tudi stranskih predmetov. Sam se je lotil učnih načrtov za solopetje, ki jih je sistematično osnoval za celotno vertikalo solopevskega izobraževanja in so končno podobo dobili v letu $1936 .{ }^{33}$ Zagotovo se je zavedal pomena sistematičnega poučevanja solopetja na Slovenskem v 20. stoletju. Najnovejši raziskovalni izsledki kažejo, da je Julij Betetto pravzaprav ustoličil smernice kakovostnega solopevskega izobraževanja v slovenskem prostoru, na podlagi katerih so bili zasnovali tudi aktualni učni načrti za pouk solopetja.

Opažamo, da Betetto v šolskem letu 1933/1934 ni poučeval solopetja, ampak se je le posvečal vodstveni funkciji, ki mu je kot človeku izjemnega reda in discipline prinesla dodatno delo in skrbi, kar se zdi povsem primerno in razumljivo. ${ }^{34} \mathrm{~V}$ ljubljanski Operi je kljub temu sicer še vedno sodeloval vse do leta 1954, a se je število njegovih poustvarjenih likov postopoma manjšalo. Nepogrešljiv je ostal v svojih življenjskih likih (Kecal, Lothario, Cerkovnik). ${ }^{35}$

31 NUK Ljubljana, Glasbena zbirka, fond Julij Betetto, mapa Konservatorij, Akademija, poučevanje, Nagovor o nastopu službe ravnatelja, 7. 12. 1933.

32 Adamič, »Naša glasbena univerza, Direktor Betetto govori o svojih delovnih načrtih," 3-4; Bohak, Julij Betetto (1885-1963) - nestor opernih in koncertnih pevcev, 57.

33 Bohak, Julij Betetto (1885-1963) - nestor opernih in koncertnih pevcev, 78-84.

34 Poročilo društva Glasbene matice v Ljubljani o šolskem letu 1933/1934, 22-35.

35 Bohak Adam, »Artistic career of Bass Julij Betetto in Ljubljana Opera«, 79. 
Poudarimo, da je Julij Betetto v slovenski kulturni prostor prinesel t. i. »dunajsko pevsko šolo«, v kateri prepoznamo izrazite belkantistične vplive. Basist svetovnega kova jo je s pridom uporabljal pri svojem pedagoškem delu ter svoje pedagoške prijeme zelo kakovostno bogatil s svojimi življenjskimi izkušnjami na umetniškem področju ter rednim prebiranjem priročnikov drugih avtorjev. Tako se je izoblikovala Betettova pevska šola, katere unikatnost je prav $\mathrm{v}$ njegovi sistematiki in premišljenem izboru tehničnih vaj ter ustrezne literature, ki so, ob redni vadbi, zagotovo privedle do zanesljivega uspeha. Zagovarjal je celostno zaokrožen in naprej fokusiran ton ter doživeto in poglobljeno interpretacijo vsakršnega dela, bodisi je šlo za antično arijo, samospev oz. pesem ali operno arijo. ${ }^{36}$

Njegovi gojenci so redno nastopali na internih vajah in sklepnih produkcijah, posebej pa velja izpostaviti, da je ob svojih gojencih včasih nastopil tudi sam. ${ }^{37}$ Tako je, med drugim, nastopil junija 1935 na III. produkciji operne šole $\mathrm{v}$ opernem gledališču kot Janek v komični operi enodejanki $V$ vodnjaku češkega skladatelja Viléma Blodka. ${ }^{38}$

Kot ravnatelj konservatorija se je redno udeleževal raznovrstnih nastopov in produkcij ter sprejemov ter velikokrat tudi ob začetku tudi spregovoril nekaj besed. Na III. jubilejni produkciji ob 1o-letnici podržavljenja, 8. junija 1936, je med drugim poudaril izjemen pomen ustanove za razvoj glasbene vzgoje slovenskega naroda ter izpostavil odličnost in preizkušenost zaposlenega pedagoškega kadra umetnikov in glasbenih pedagogov, ki vodijo posameznika od začetkov do samostojnega umetniškega udejstvovanja:

Povsem napačno je mnenje premnogih staršev, da je za začetni glasbeni pouk dober vsak poljuben učitelj. Kakor mora imeti vsaka stavba soliden temelj, tako je nujno zaupati prvi glasbeni pouk samo preizkušenemu in najbolje kvalificiranemu učitelju. Iz topredmetnega napačnega naziranja izvirajoči grehi se v poznejših letih bridko maščujejo. Le pod vodstvom preizkušenih in strokovno popolno kvalificiranih učnih moči, s kakršnimi razpolaga naš konservatorij in šola Glasbene Matice, mora najti glasbe učeča se mladina garancijo napredka. In le napredek je ona magična sila, $k i$

Bohak, Julij Betetto (1885-1963) - nestor opernih in koncertnih pevcev, 92-93. 
vzbudi v gojencu veselje do študija in vežbanja glasbene tvarine. A $v$ veselju in radosti do muziciranja, negovanim $z$ veščo roko kvalificiranega pedagoga, smemo in moremo iskati vir uspehov. Vrednote pravilne, solidne glasbene izobrazbe so za vsakogar neprecenljive vrednosti. ${ }^{39}$

Kljub vodstveni funkciji je bil Betetto še vedno predan profesor in njegovi učenci so se še vedno redno pojavljali na večini nastopov in produkcijah. Tako sta se na junijskih jubilejnih produkcijah ob koncu šolskega leta 1935/36 predstavili tudi učenci srednje stopnje konservatorija, med drugim baritonist Franc Hvastja ter basist Friderik Lupša, ki sta s svojima nastopoma požela velik aplavz in val navdušenja.$^{40}$ Izpostavimo, da je Hvastja leta 1939 diplomiral na konservatoriju in se uveljavil kot solist ljubljanske Opere, Friderika Lupšo pa je, ko je obiskoval 3. letnik, opazil takratni dirigent ljubljanske Opere Niko Štritof in ga angažiral kot opernega solista že v času študija. ${ }^{41}$ Opažamo, da je Betetto imel vsestranski občutek za delovanje ljubljanskega ansambla in je imel tudi velik vpliv na podmladek ljubljanske Opere. Na produkcije konservatorija je redno vabil operne dirigente, da bi spoznali najperspektivnejše pevce, ki bi se že v času študija lahko predstavili na odru Talijinega hrama in kasneje morda dobili možnost nadaljnjega rednega opernega poustvarjanja.

Državni konservatorij je v letu 1937 podvojil pedagoška prizadevanja, a ne toliko po številu učencev kot po kvaliteti nastopov in gostovanj. Dokazali so visoko raven umetniškega poustvarjanja, za kar so gotovo bili zaslužni tudi profesorji z veliko znanja in pedagoških izkušenj, med katerimi je bilo kar nekaj uveljavljenih imen, kot so Julij Betetto, violinista Karel Jeraj in Karlo Rupel, pianisti Marijan Lipovšek, Janko Ravnik in Zora Zarnik, skladatelja Slavko Osterc in Pavel Šivic, glasbena pedagoginja Angela Trost in drugi. ${ }^{42} \mathrm{~V}$ komorno vokalnih, instrumentalnih in orkestralnih ter zborovskih zasedbah so se pojavljali novi solisti - konservatoristi. Nastopali so $\mathrm{v}$ lastni hiši, Filharmonični dvorani ter $\mathrm{v}$ dramskem in opernem gledališču. Pedagogi, zaposleni na konservatoriju, so komentirali sporede in predavali o pomenu glasbene vzgoje. Tako je, med drugim, Betetto v začetku novem-

39 Poročilo društva Glasbene matice v Ljubljani o šolskem letu 1935/1936 (Ljubljana: Glasbena matica, 1936), 3-6.

40 Ibid., 13-14.

41 Poročilo društva Glasbene matice v Ljubljani o šolskem letu 1937/1938 (Ljubljana: Glasbena matica, 1938), 10; Kuret, Sto slovenskih opernih zvezd, 89, 95.

42 NUK, Glasbena zbirka, mapa Julij Betetto, podmapa Konservatorij, „Dopis ravnateljstvu Državnega konservatorija«, Ljubljana, 24. 8. 1937. 
bra 1938 sodeloval pri izvedbi simfonične kantate Zedinjenje Lucijana Marije Škerjanca za soliste, zbor in orkester. Ob zboru Glasbene matice in orkestru ljubljanske filharmonije so se pod taktirko Mirka Poliča kot solisti predstavili takratni solisti ljubljanske Opere, sopranistka Valerija Heybal, altistka Mila Kogej ter tenorist Svetozar Banovec. ${ }^{43}$ Naglasimo, da je Betetto, kljub izjemno zaposlenemu urniku, redno nastopal kot solist na matičinih koncertih skozi celotno svojo umetniško kariero.

Kot je znano, so se v letu 1937 ob sporočilu, da beograjsko ministrstvo za prosveto pripravlja uredbo o srednjih in višjih glasbenih šolah, $v$ Ljubljani sešli zastopniki Državnega konservatorija in šole Glasbene matice. $\mathrm{Ob}$ podpori Društva prijateljev Glasbene akademije so se dogovorili, da je napočil čas za ustanovitev visoke glasbene šole v Ljubljani - Glasbene akademije. Proces prestrukturiranja se je pričel v Beogradu, kmalu zatem še v Zagrebu in Ljubljani, ko je bila leta 1939 ustanovljena Glasbena akademija kot prva samostojna visoka šola na stopnji fakultete $\mathrm{v}$ zgodovini slovenskega glasbenega šolstva. ${ }^{44}$ Kot človek vsestranskih kvalitet je pri ustanovitvi akademije zelo intenzivno sodeloval tudi Julij Betetto, ki je postal zraven Antona Trosta in Stanka Premrla eden izmed prvih treh imenovanih profesorjev, tri leta (1942-1945) pa je bil tudi rektor te ustanove. ${ }^{45}$

\section{Bibliografija}

Adamič, Emil. »Dve javni produkciji konservatoristov v Ljubljani«. Jutro 8, št. 150 (1927): 4 .

Adamič, Emil. »Naša glasbena univerza, Direktor Betetto govori o svojih delovnih načrtih«. Jutro 15, št. 196 (1934): 3-4.

Anon. »Mateju Hubadu«. Slovenski narod 52, št. 145 (1919): 4.

Anon. »Slavnostni koncert Glasbene Matice«. Jutro 19, št. 258 (1938): 12.

Bohak, Tina. Julij Betetto (1885-1963) - nestor opernih in koncertnih pevcev. Ljubljana: Akademija za glasbo, 2015.

Bohak Adam, Tina. "Artistic career of Bass Julij Betetto in Ljubljana Opera». De musica disserenda 14, št. 2 (2018): 73-88. https://doi.org/10.3986/dmd14.2.05.

Hubad, Matej. »Jugoslovanski konservatorij Glasbene Matice v Ljubljani«. Učiteljski tovariš 59, št. 34 (1919): 1.

43 Anon., »Slavnostni koncert Glasbene Matice«, Jutro 19, št. 258 (1938): 12.

44 Letno poročilo društva Glasbene matice v Ljubljani za poslovno dobo 1938 in za šolsko leto 1937/1938 (Ljubljana: Glasbena matica, 1938), 4-7.

45 Bohak, Julij Betetto (1885-1963) - nestor opernih in koncertnih pevcev, 64-66. 
Izvestje Glasbene matice v Ljubljani o 36. društvenem letu 1907/19o8. Ljubljana: Glasbena matica, 1908.

Kuret, Primož. Sto slovenskih opernih zvezd. Ljubljana: Prešernova družba, 2005.

Letno poročilo društva Glasbene matice v Ljubljani za poslovno dobo 1938 in za šolsko leto 1937/1938. Ljubljana: Glasbena matica, 1938.

NUK Ljubljana, Glasbena zbirka, fond Glasbena matica, zapisniki seje odbora 1919-1921.

NUK Ljubljana, Glasbena zbirka, fond Julij Betetto, mapa Konservatorij.

Osebni dnevnik Julija Betetta, v zasebni lasti avtorice.

Ožbalt, Andrej. »Matej Hubad - življenje in delo«. Dipl., Univerza v Ljubljani, 1998.

Poročila društva Glasbene matice v Ljubljani o šolskih letih 1928/1929-1939/1940. Ljubljana: Glasbena matica, 1929-1940.

Uredništvo. »Nove muzikalije«. Nova muzika 2 (1929): 1. 